\title{
Hodgkin's Granuloma
}

National Cancer Institute

\section{Source}

National Cancer Institute. Hodgkin's Granuloma. NCI Thesaurus. Code C6914.

An obsolete term referring to Hodgkin lymphoma. 